\author{
Khalel A., Işıl Altun \\ Kocaeli University, Turkey \\ e-mail: isilaltun@ hotmail.com
}

\title{
MODELING CROSS-CULTURAL SCIENTIFIC DISCUSSIONS
}

\begin{abstract}
For professional-branch communicative preparation of students of language specialties for effective participation in this scientific event in a foreign language it is necessary: a) to determine the conceptual content of the term "intercultural scientific discussion"; b) to identify the nomenclature of sequential fragmentation of intercultural communicative macro education in the micro education term on the basis of didactic-oriented content analysis of the system of activity for participants of intercultural scientific discussion in the socio-cultural academic role; c) to identify the main types of professional task assignments (in the context of international and national universities standards) created by a hierarchical system of foreign language for consistent and dynamic communicative and cognitive development of students as an equal participant of intercultural academic communication. The article deals with the problems of methodological modeling of intercultural scientific discussion in a foreign language as an international academic measure implemented through intercultural academic interaction of representatives of various cultural,linguistic and research communities.
\end{abstract}

Key words: communication, intercultural, intercultural communicative, problem tasks.

Introduction. Culture is a way of thinking and living whereby one picks up a set of attitudes, values, norms and beliefs that are taught and reinforced by other members in the group. This set of basic assumptions and solutions to the problems of the world is a shared system that is passed on from generation to generation to ensure survival. A culture consists of unwritten and written principles and laws that guide how an individual interacts with the outside world. Members of a culture can be identified by the fact that they share some similarity. They may be united by religion, by geography, by race or ethnicity.

Our cultural understanding of the world and everything in it ultimately affects our style of communication as we start picking up ways of one's culture at around the same time we start learning to communicate. Culture influences the words we speak and our behavior. We will define a range of the directions of formation of ability to cross-cultural communicative competence in the conditions of training in a foreign language of the senior classes. They include:

- the multicultural direction (enrichment of the culture due to acceptance of another, readiness for development of other culture): acceptance of new knowledge of foreign culture for deeper knowledge; respect for all cultures; vision in foreign-language culture that distinguishes us from each other that pulls us together and unites; ability to look at events and their participants not from the point of view, and from positions of other culture;

- tolerance (aiming at interaction, ability to communicate): ability to interact with people of other culture on the basis of the accounting of their values, norms, representations; ability to correct the behavior in the course of communication on the person of other culture; lack of rigidity in behavior; ability to empathize, responding to emotions, experiences of carriers of foreign culture; to feel and understand mood of people;

- behavioural direction: the adequate behavior accepted in business professional spheres; finding of constructive compromises; ability to come into contact and to support him;

- the linguo socio cultural direction (use of linguistic means of language according to cultural standards of language in a professional field of activity): ability to exchange opinions; ability to listen, pay attention to the interlocutor; to raise the questions pushing to an explanation told. 
The problem of formation of ability to cross-cultural communicative competence is carried out in the course of speech interaction: auditions, readings, speakings, letters as in the course of classroom occupations, and out-of-class work with teacher.

We will consider the principles and approaches which are been the basis for formation of ability to cross-cultural communicative competence.

Literature review. Methodological interest in the study of the debate in foreign language appeared in the $70 \mathrm{~s}$ of the last century, and it contributed to the publication of the first methodological works about the discussion in the teaching system of foreign language. Thereafter, this issue has been a subject of research in the field of language pedagogy. As a result, P. B. Gurvich, E. V. Shantarina, N. E. V. Shuvalova, E. V. In Smirnova's works it became possible to define a certain set of discussion skills and offer forming and developing tasks on the basis of the studied foreign language material. The methodological significance of these works is still high. However, it should be noted that in the works of the above-mentioned authors were not paid attention to many objective and subjective reasons of intercultural aspect. However, it is doubtful whether it is possible to create a methodical model of teaching students academic discussion, which is important for the effectiveness of intercultural academic discussion in the context of civilization and the modern multilingual and multicultural world, striving for "Open education", "Open science", "Open innovation", without paying full attention to this issue. At the same time, in the field of domestic linguistics, there is still a tendency to ignore the intercultural aspect of teaching discussions using methodological researches in Universities. This process continues in domestic science, despite the fact that such universal competencies as "communication" and "intercultural interaction" (in the formation of these competencies, the University plays a key role in language teaching), are manifested as educational results in all languages studied in the Universities.

Material and Methods. While modeling intercultural scientific debate in terms of foreign training of students of a magistracy it is advisable to divide intercultural communicative macro education into micro educational level. To analyze of original materials, video recordings of the scientific discussion (which took place at international conferences and scientific and methodological seminars in English or appropriate languages in 2014-2018) and identify the nomenclature of intercultural communicative macro-and micro education of the organizers and other participants of the scientific discussion for linguo-didactic purposes, as well as the definition of their range in the performance of various socio-cultural academic roles (Afuach 2003:86 p). Based on the expertise of international scientific and practical seminars initiated by the European Council and the European Union, we include the following roles which are in the socio-cultural academic role:

- Chairman and / or Leading Organizer;

- Expert / experts;

- Moderator / group of moderators;

- Facilitator/ group of facilitators;

- Representatives of scientific schools and national academic associations.

There are main macro and micro educational nomenclature common to most participants of international science workshops associated with their specific cross-cultural roles.

Results and Discussion. In the absence of the above conclusion "Vocational training, a professionally-oriented complex of problem-communicative tasks necessary to ensure the rational and effective participation of undergraduate students majoring in intercultural linguistic, cultural and research environment with representatives of the academic community in the research environment that has been focused on the needs to integrate competence and problem positions, allowing to create tools for methods of creating a problem-oriented environment that meets the regulatory and methodological requirements of the professional standard" Teacher of vocational education and additional vocational education" the desire would be a utopia.

Communication represents socially caused process of transfering information and exchanging thoughts, feelings between people in various spheres of informative, labor and creative activity. 
Communication is the oral verbal and nonverbal interaction, realized in practical activities. Opening essence of the concept "cross-cultural communicative competence", O. A. Leontovich emphasizes that cross-cultural competence "is a conglomerate of three components: language, communication and cultural competence.

We agree with O. A. Leontovich's opinion about education, "which possesses own signs other than each of the components taken separately. Language competence is responsible for a right choice of the language means adequate for a communicative situation; communicative competence turns on mechanisms, receptions and the strategy necessary for ensuring effective process of communication; the concept of cultural competence coincides with concept of cultural literacy and assumes knowledge of political realities, phrase logical units, terms, dialecticisms etc. More specifically the essence of cross-cultural communicative competence I. L. Pluzhnik has defined as: "... it represents functional abilities to understand views and opinions of representatives of other culture, to correct the behavior, to overcome the conflicts in the course of communication, to recognize the right for existence of various values, standards of behavior."

We will address to the following:

- understanding by trainees of own national culture and native language; for this purpose a combination of communicative and activity approach with socio cultural competence that gives the chance to form not only concrete cultural ideas of the countries the foreign languages, the people and communities, but also to stimulate knowledge of cultural material about the native land, to develop representation of native culture in a foreign language in the foreign-language environment, in the conditions of cross-cultural communication;

- a support on background knowledge, a sociocultural background in the context of which the learned foreign language because the background knowledge playing a part when using language and by that influencing foreign-language communication competence of trainees is necessary for adequate cross-cultural communication with native speakers functions;

- training in lingual interaction in the context of dialogue of cultures that assumes expansion of a circle of cultures and civilizations, understanding "trainees of as the cultural and historical subjects which are carriers and spokesmen not of one, but a number of the interconnected cultures, for preparing them to perform in the society of a role of the subject of dialogue of cultures"

- the humanistic psychological approach of the educational environment understood as promotion of the trainee as the subject of cross-cultural communication and as the subject of language educational process and allowing to speak about shift of emphasis in the course of training in a foreign language from teaching activity on activity trained, its formation as creative person;

- the interactive nature of activity of trainees assuming application of the modern technologies providing updating and development of personal qualities of school students (training in cooperation, a method of projects, information technologies (Internet), distance learning on the basis of computer telecommunications); the differentiated approach to trainees putting them in a choice situation inducing to independence and activity, development of a reflection

Interactive nature of activity trained on classes in a foreign language is caused by creation of the educational and speech situations inducing trainees to need for foreign and speech communication for conditions which are same with the natural. The educational and speech situation is defined as set of the speech conditions necessary in order the trainee to correctly carry out speech action according to the planned communicative task. Situations can be designed on the basis of the studied foreign texts and can be considered in connection with work on them, and can be created out of communication with texts and join in occupations as exercises on development of educational and speech activity. The speech situation allows to define relevance of speech activity on the basis of a subject, to provide communicative motivation; to reveal aspects of communicative communication by means of modeling by conditions (I agree - I don't agree, doubt - the statement, unambiguity of the statement - free discussion, obstacles to action implementation - opportunity to carry out it, etc.); on the basis of structural components a speech situation (the formulation of communicative tasks) to make the impact inducing communication, intension to the statement. 
Mastering the system of interaction debate, especially in conditions of intercultural academic communication is a complex of methodological system that requires the creation of a hierarchical system of professionally-oriented problem communicative tasks to prepare students of language specialties for intercultural academic communication (DasilvaM.C. 2013: 13). Therefore, when modeling intercultural scientific discussion of linguo-didactic purpose in this issue it is rational to use the following:

1. Cultural-oriented communicative tests (B2) (aimed at developing the ability of the communicative-linguistic competence to select adequate linguistic means of expression in debates related to intercultural discussion);

2. Professionally-oriented cultural,educational and search tasks (contributing to the development of control of verbal and non-verbal activities of participants for intercultural scientific discussion in foreign language, the generalization of their communicative and pragmatic observations, the definition and generalization of the activities of participants for the scientific discussion and the Chief-organizer of the scientific seminar, moderators and facilitators in the case perform their academic functions);

3. Professionally-oriented communicative and pragmatic tasks (including the search for ways to overcome the communicative and cognitive barriers typical of Kazakh people in interaction with representatives of other academic linguo-cultural communities, formed on the materials of problem situations in the framework of the international scientific seminar, as well as the definition of professional and communicative tasks necessary to solve by communicators in the process of academic interaction);

4. Academic role-playing games aimed at learning the real socio-cultural academic roles;

5. To research case study involved in the process of modeling the scientific seminar as a communicative event, characterized by well-established and strictly regulated rules of the academic game.

Conclusion. So, the nomenclature of intercultural communicative knowledge recommended as a result of the linguo-cultural description of intercultural academic discussion and its combination with the main socio-cultural academic roles, as well as professionally-oriented problem communicative tasks are necessary prerequisites for the design of a holistic model of training students to intercultural communication with representatives of various linguistic and cultural academic communities in foreign language. Proceeding from structure of cross-cultural communicative competence and considering the principles on the basis of which formation of the functional abilities allowing to assess adequately a communicative situation and to realize communicative intention is carried out, we will define the pedagogical conditions necessary for ensuring effective process of communication.

They include:

- functioning of pedagogical space through creation and use of communicative situations, the importance of manifestation of a complex of the abilities necessary for successful participation in cross-cultural communication;

- motivational readiness of trainees for learning of foreign language which components are focus, activity, the object and subject relations in the course of educational activity, the individual and psychological properties of the personality stimulating ability to carry out cross-cultural communication with native speakers;

- creation of positive emotional climate in all range of the educational field promoting education of the person of culture committed to universal values, which absorbed in itself richness of cultural heritage of the last people and the people of other countries seeking for mutual understanding with them and ready to carry out interpersonal and cross-cultural communication.

Development of ability to cross-cultural communication competence conducts to positive personal changes trained on the basis of a reflection, focus on comprehension of values of other culture, on deepening of feeling of civic consciousness in the course of the appeal to native culture and language. 


\section{References}

Afuah, A. (2003), Business Models: A Strategic Management Approach. New York: McGraw-Hill/ Irwin. Baden-Fuller, CH. \& Morgan, M. S.

Chesbrough, H. (2006), Open Business Models: How to Thrive in the New Innovation Landscape. Boston: Harvard Business School Press. Debelak, D.

DaSilva, M.C. and P. Trkman (2013), LongRangePlanning. Business Model: What It Is and What It Is Not (1-11).

Korošová, V. \& Synek, V. (2011), Grécky oikos a nevalný val. Trend, No. 29

Magretta, J. (2010). Why Business Models Matter. Harward Business Review on Business Model Innovation. USA: HBR Publishing Corporation.

Mullins, J. \& Komisar, R. (2009), Getting to Plan B: Breaking Through to a Better Business Model. USA: Harvard Business Press.

Onetti, A., A. Zucchella, V.J. Marian and P.P. McDougall-Covin (2012), Journal of Management and Governance. Internationalization, innovation and entrepreneurship: business models for new technology-based firms, Journal of Management \& Governance, 3: 337-368.

Teece, J. D. (2010), Business Models, Business Strategy and Innovation. Long Range Planning, 43(2), 172-194. Site: http://dx.doi.org/10.1016/j.lrp.2009.07.003

Rappa, M. (2010), Business Models on the Web. Retrieved May 17, 2010, from http:// digitalenterprise.org/models/models.html 1.2. 3. 4. 5. 6. 7. 8. 9. 10.11. 12. 13. 14. 15. joc4 -2014 _ v3b. indd 39 30.12.2014 17:11:25 40 Journal of Competitiveness

Slávik, Š. (2011), Komparatívna analýza podnikatel'ských modelov. Ekonomika a manažment, 11(3), 23-43.

Slywotzky, A.J. (1996), Value Migration, Harvard Business Review Press,Boston,MA.

Xavier L., D. Benoit and J. Ventura (2010), M@n@gement. Business Models as a Research Program in Strategic Management: An Appraisal based on Lakatos, vol. 13 no. 4: 214-225.

Zott, C. and R. Amit (2010), LongRangePlanning. Business Model Design: An Activity System Perspective, 43: 216-226.

Watson, D. (2005), Business Models. Petersfield: Harriman House Ltd. Site: www.science.kz

Кшалел А, Асил Алтын

Кожаели университеті, Түркия

e-mail: isilaltun@hotmail.com

\section{МӘДЕНИЕТАРАЛЫК ҒЫЛЫМИ ПІКІРТАЛАСТАРДЫ МОДЕЛЬДЕУ}

Аңдатпа. Тілдік мамандықтардағы студенттерді шет тіліндегі аталған ғылыми шараға тиімді қатыстыстыруда кәсіби-салалық коммуникативті дайындау үшін мыналар қажет: а) «мәдениетаралық ғылыми дискуссия» терминінің ұғымдық мазмұнын анықтау, б) мәдениетаралық ғылыми дискуссияға қатысушылардың әлеуметтік-мәдени академиялық рөліндегі іс-әрекет жүйесін дидактикалық-бағытталған контент-сараптау негізінде мәдениетаралық коммуникативтік макробілімді бірте-бірте микробілім терминінде бөлшектеудің номенклатурасын анықтау, в) Мәдениетаралық академиялық қарымқатынастың тең құқылы қатысушысы ретінде студенттердің дәйекті және динамикалық коммуникативтік-когнитивті дамуы үшін ШТ иерархиялық жүйемен құрылған кәсібипрофилді мәселелік тапсырмалардың негізгі түрлерін (халықаралық және ұлттық университеттер стандарты контексінде) анықтау. Бұл мақалада шет тіліндегі мәдениетаралық ғылыми дискуссияны әдістемелік моделдеудің әртүрлі мәдени-тілдік және ғылыми- 
зерттеушілік қауымдастық өкілдерінің мәдениетаралық академиялық өзара әрекеттесуі арқылы жүзеге асатын халықаралық академиялық шара ретіндегі мәселелері қарастырылады.

Түйін сөздер: мәдениетаралық, әлеуметтік,академиялық

\author{
А. Халель, Алтул Исиль \\ Университет Коджаэли, Турция \\ e-mail: isilaltun@hotmail.com
}

\title{
МОДЕЛИРОВАНИЕ МЕЖКУЛЬТУРНЫХ НАУЧНЫХ ДИСКУССИЙ
}

\begin{abstract}
Аннотация. Определено понятие «межкультурная научная дискуссия»; дано определение номенклатуры последовательной фрагментации межкультурного коммуникативного макрообразования, роли межкультурной научной дискуссии в социокультурной академической роли дидактически-ориентированного контент-анализа; определены основные виды профессионального назначения и межкультурного академического общения. Получившие развитие во второй половине XX в. процессы глобализации и интернационализации актуализировали такой аспект социальной коммуникации, как взаимодействие в межкультурной среде. Например, чрезвычайно важные функции в процессе межкультурного взаимодействия выполняет невербальная коммуникация. Используемые при этом знаки, действия и символы могут иметь различное значение для его участников и оказывать влияние как на процесс взаимодействия, так и на его результаты. Многое зависит от изначального настроя, от установок человека, который готовится осуществлять межкультурный контакт или уже его осуществляет. Основными барьерами, которые снижают эффективность интеракций, являются различия когнитивных схем, используемых представителями разных культур. Наиболее ярко дифференциация моделей восприятия проявляется при столкновении с иным мировоззрением, мироощущением и т.п. В данной статье рассматриваются различные культурные, лингвистические и исследовательские сообщества в области межкультурного диалога.
\end{abstract}

Ключевые слова: коммуникация, социокультурные академические роли 